\title{
PREDICTION OF OUTCOME IN PATIENTS WITH SEPSIS USING CRP, LDH AND APACHE-II SCORING SYSTEM
}

Arvind M. N1, Nayana H. $K^{2}$

${ }^{1}$ Associate Professor, Department of Internal Medicine, KIMS, Bengaluru.

${ }^{2}$ Senior Resident, Department of Internal Medicine, KIMS, Bengaluru.

\section{BACKGROUND}

ABSTRACT

Sepsis is one of the commonest cause for mortality in intensive care unit. There is continuum of severity ranging from sepsis to severe sepsis and septic shock. Several biomarkers and clinical scoring systems have been used to assess the severity and outcome of sepsis. A delay in making the diagnosis and instituting appropriate therapy has been associated with increased mortality. This study is undertaken to show that early recognition of sepsis and prediction of outcome of sepsis using CRP, LDH and APACHE-II score with appropriate treatment reduces the mortality rate.

The objectives of this study are-

- $\quad$ To find out the extent of CRP elevation in sepsis.

- $\quad$ To assess and compare the CRP level and APACHE-II score as a predictor of outcome in patients with sepsis.

- To analyse serum LDH as distinguishing clinical biomarker and as a predictor of mortality in sepsis patients and to compare with CRP elevation and APACHE-II score.

\section{MATERIALS AND METHODS}

We performed a prospective observational study on patients admitted due to sepsis between November 2014 and September 2016. A total of 100 patients in sepsis were included after considering the inclusion and exclusion criteria.

\section{RESULTS}

The mean value of CRP in sepsis was $25.14 \pm 16.84 \mathrm{mg} / \mathrm{dL}$. It ranged between $3-80 \mathrm{mg} / \mathrm{dL}$. The mean values of CRP were significantly higher among those who died $(36.40 \pm 18.92 \mathrm{mg} / \mathrm{dL})$ compared to patients who recovered $(17.63 \pm 9.81 \mathrm{mg} / \mathrm{dL}) \mathrm{from}$ sepsis $(\mathrm{t}=-6.493, \mathrm{p}=<0.001)$. The mean values of CRP were higher among those with $>3$ organs involvement $(27.06 \pm 18.37$ $\mathrm{mg} / \mathrm{dL})$ compared to patients with $\leq 3$ organs involvement $(20.87 \pm 12.01 \mathrm{mg} / \mathrm{dL})$ in sepsis; however, it was not statistically significant $(\mathrm{t}=-1.715, \mathrm{p}=0.09)$. The mean values of APACHE-II score was significantly higher among who died $(22.10 \pm 7.71)$ compared to patients who recovered $(16.95 \pm 7.25)$ from sepsis $(t=-3.391, p=<0.001)$. LDH was also one of the significant independent predictors. The combined model with LDH, APACHE-II and CRP showed the best accuracy of $87.0 \%$ in predicting the outcome of sepsis. Among the patients with sepsis, unit rise in LDH reduces the odds of survival (reduces by $98.0 \%$ ), unit rise in CRP (the odds of survival reduce by 93.0\%) and with unit rise in APACHE-II score (the odds of survival reduces by $80.0 \%$ ).

\section{CONCLUSION}

- $\quad$ The proportion of patients who died were significantly more among those with CRP more than $18 \mathrm{mg} / \mathrm{dL}$ compared to those with $\leq 18 \mathrm{mg} / \mathrm{dL}$.

- $\quad$ APACHE-II and CRP were the significant independent predictors. Among CRP and APACHE-II, the best indicator of mortality in sepsis is CRP followed by APACHE-II score.

- $\quad$ LDH is a good indicator of mortality among patients with sepsis compared to CRP and APACHE-II score.

\section{KEYWORDS}

CRP, LDH, APACHE-II, Sepsis.

HOW TO CITE THIS ARTICLE: Arvind MN, Nayana HK. Prediction of outcome in patients with sepsis using CRP, LDH and APACHEII scoring system. J. Evolution Med. Dent. Sci. 2018;7(03):273-278, DOI: 10.14260/jemds/2018/61

\section{BACKGROUND}

Sepsis is one of the oldest and most elusive syndromes in medicine and ranks in the top ten causes of death. The primary cause whether infectious or non-infectious, it triggers an uncontrollable inflammatory response. Sepsis can be reversed, but as it progresses to severe sepsis and septic

'Financial or Other Competing Interest': None.

Submission 26-12-2017, Peer Review 07-01-2018,

Acceptance 09-01-2018, Published 13-01-2018.

Corresponding Author:

Dr. Arvind M. N,

$42 / 1,9^{\text {th }}$ Main, $4^{\text {th }}$ Cross, RMV Extension,

Sadashivnagar,

Bengaluru-560080

E-mail: drarvind_mn@yahoo.co.in

DOI: $10.14260 /$ jemds $/ 2018 / 61$ shock the mortality rate substantially increases. ${ }^{1}$ Multi-organ dysfunction syndrome is well established as the final stage of the continuum. ${ }^{2}$ In more than one-third of the patients, aetiology is never determined even till death or discharge. ${ }^{2}$

Patients admitted to the ICU need aggressive supportive management as well as detailed investigations to reverse the cause. ${ }^{3}$ In the crucial hours, which determine the prognosis of the patient, the physician has to depend on clinical symptoms and demographic data to aid in diagnosis and management. Even the cultures and serology are available only after 24 to 48 hours.

Early initiation of appropriate effective antimicrobial therapy is essential for a favourable outcome in the patient with sepsis. ${ }^{4,5}$ Failure to initiate appropriate therapy correlates with increased morbidity and mortality. ${ }^{6}$ 
Hence, guidelines recommend empirical broad-spectrum antibiotics that will cover all likely pathogens as well as supportive care, early recognition and treatment of complications and intensive monitoring to prevent worsening of sepsis. ${ }^{3}$

With advances in intensive care, increased awareness and dissemination of evidence-based guidelines, clinicians have taken large strides in reducing the risk of imminent death associated with sepsis. Various clinical, biochemical and haematological parameters in septic patients serve as indicators of organ dysfunction and hence can be used to define the prognosis in a patient with sepsis.

Acute Physiology and Chronic Health Evaluation II (APACHE-II) score is one of the scoring systems that has shown a good calibration and discriminatory value across a range of disease processes, and remains the most commonly used International severity scoring system worldwide.7,8

C-reactive protein (CRP) is an acute-phase reactant, which increases markedly within hours after tissue injury. ${ }^{9}$ Changes in plasma CRP levels can be useful in the diagnosis and follow-up.

Few studies have shown the prognostic value of serum LDH in patients with sepsis and presence of very high isolated $\mathrm{LDH}$ warrants thorough investigation for the presence of severe underlying disease, mostly metastatic cancer, haematologic malignancies and infection.

There are many scores available at present as described above. But our study focuses on mainly Acute Physiology and Chronic Health Evaluation II (APACHE-II) score, C-reactive Protein (CRP) and Lactate Dehydrogenase (LDH) as predictors of outcome (Mortality) of sepsis in the current ICU settings and very few studies discusses or compares and contrasts the use of all the three, viz. CRP, APACHE-II and $\mathrm{LDH}$ as predictors of mortality in sepsis.

\section{Objectives}

- $\quad$ To find out the extent of CRP elevation in sepsis.

- To assess and compare the CRP level and APACHE-II score as a predictor of outcome in patients with sepsis.

- To analyse serum LDH as distinguishing clinical biomarker and as a predictor of mortality in sepsis patients and to compare with CRP elevation and APACHE-II score.

\section{MATERIALS AND METHODS}

\section{Source of Data}

Patients diagnosed of sepsis in the inpatient Department of General Medicine, KIMS, Bengaluru was taken up for the study considering the inclusion and exclusion criteria.

\section{Method of Collection of Data}

The diagnosis of sepsis was established on clinical history, physical examination and investigations.

Informed consent was taken from the patient.

A pre-structured and pretested proforma was used to collect the data.

Baseline data including socio-demographic data and medical history were collected. Clinical examination and relevant investigations were done.

\section{Sample Size}

100 patients with sepsis were admitted to Department of Medicine.

\section{Study Period}

One and a half years including follow-up time from November 2014 to September 2016.

\section{Inclusion Criteria}

- $\quad$ Age group $>18$ yrs.

- Patients with evidence of sepsis on admission and gave informed consent.

\section{Exclusion Criteria}

- Pregnant women.

- Patients with hepatitis and known liver disorder.

- Patients with crush injury, rhabdomyolysis, decubitus ulcers.

- $\quad$ Patients with retroviral disease.

\section{Study Design}

Observational study.

\section{Sampling Methods}

Purposive sampling.

\section{Duration of Study}

18 months.

\section{Statistical Method}

Data were presented in means, proportions and standard deviations. Analysis was done using statistical techniques such as chi-square test, independent ' $t$ ' test and Pearson's correlation. A multivariate logistic regression model was applied to those variables significant on univariate analysis to assess the independent association between each risk factor and mortality after adjusting for other risk factors. The area under the receiver operating characteristic (ROC) curve for the assessment of the predictive value of mortality using CRP, LDH and APACHE-II scores were constructed. The best cut-off values considering both maximum sensitivity and specificity to predict the mortality was calculated using Youden's index. Standard statistical package was used for data analysis. A ' $p$ ' value of $<0.05$ was taken as statistically significant.

\section{RESULTS}

1. In the present study, out of 100 study subjects, 55 (55.0\%) were males and 45 (45.0\%) were females.

2. The mean age was $49.78+17.13$ years with a range from 18 to 90 years.

3. The mean age of females and males were $46.36+18.90$ years and $52.58+15.14$ years respectively.

4. Majority of the subjects were males in all the age groups, except for the age group $\leq 35$ years.

\begin{tabular}{|c|c|c|}
\hline Particulars & $\begin{array}{c}\text { Survived } \\
{[\mathbf{n = 6 0 ]}} \\
\text { (Mean } \pm \text { SD) }\end{array}$ & $\begin{array}{c}\text { Died }[\mathbf{n = 4 0 ]} \\
\text { (Mean } \pm \text { SD) }\end{array}$ \\
\hline $\begin{array}{c}\text { C-Reactive Protein } \\
\text { (mg/L) }\end{array}$ & $17.63 \pm 9.81$ & $36.40 \pm 18.92$ \\
\hline $\begin{array}{c}\text { Serum Lactate } \\
\text { Dehydrogenase (U/L) }\end{array}$ & $267.47 \pm 120.58$ & $471.18 \pm 167.32$ \\
\hline APACHE-II Score & $16.95 \pm 7.25$ & $22.10 \pm 7.71$ \\
\hline
\end{tabular}

Table 1. Mean Values of Few of the Important Biomarkers

of Mortality Observed in Sepsis among the Study Population with different Survival Outcomes 
The above table describes that the mean values and standard deviations of C-reactive protein, serum lactate dehydrogenase and APACHE-II scores were higher among who died compared to patients who recovered from sepsis.

\begin{tabular}{|c|c|c|c|c|}
\hline $\begin{array}{c}\text { Age in } \\
\text { Years }\end{array}$ & $\begin{array}{l}\text { Survived } \\
\text { (Row \%) }\end{array}$ & $\begin{array}{c}\text { Died } \\
\text { (Row \%) }\end{array}$ & Total & $\begin{array}{l}\chi 2 \text { Value } \\
(P \text {-Value })\end{array}$ \\
\hline$\leq 35$ & $15(62.5)$ & $09(37.5)$ & $24(24.0)$ & \multirow{5}{*}{$\begin{array}{c}3.18 \\
(0.36)\end{array}$} \\
\hline $36-50$ & $20(66.7)$ & $10(33.3)$ & $30(30.0)$ & \\
\hline $51-65$ & $18(62.1)$ & 11 (37.9) & $29(29.0)$ & \\
\hline$>65$ & $07(41.2)$ & 10 (58.8) & \begin{tabular}{|l|}
$17(17.0)$ \\
\end{tabular} & \\
\hline Total & $60(60.0)$ & $40(40.0)$ & $\begin{array}{c}100 \\
(100.0)\end{array}$ & \\
\hline
\end{tabular}

Table 2. Association of Occurrence of Death/Recovery due to Sepsis with Age

Among the study subjects with sepsis, majority i.e. 59 $(59.0 \%)$ were in the age group of $36-65$ years. Among the patients who died of sepsis, most (58.8\%) of them were in the age group of $>65$ years and among the recovered majority $(66.7 \%)$ were in the age group of 36 - 50 years. However, the association of age with outcome of sepsis was not statistically significant $(\mathrm{P}>0.05)$.

Among the study subjects with sepsis, majority i.e. 55 $(55.0 \%)$ were males. Among the patients who died of sepsis and who recovered from sepsis, most of them were males. However, the gender was not significantly associated with the outcome of sepsis ( $\mathrm{P}>0.05)$.

In the percentage of outcome of sepsis in terms of survivability based on the number of organs involved, at least 3 organs involvement was the majority, i.e. $60.0 \%$ of them did not survive. Among those with 5 organs involvement, none $(0.0 \%)$ of them survived of sepsis.

\begin{tabular}{|c|c|c|c|c|}
\hline Particulars & Survived [n= 60] (Mean \pm SD) & Died [n= 40] (Mean \pm SD) & t-value (95\% C.I) & $\boldsymbol{P}$-value \\
\hline C-Reactive Protein & $17.63 \pm 9.81$ & $36.40 \pm 18.92$ & $\begin{array}{c}-6.493 \\
{[-24.503 \text { to- } 13.031]}\end{array}$ & $<0.001^{*}$ \\
\hline $\begin{array}{c}\text { Serum Lactate } \\
\text { Dehydrogenase }\end{array}$ & $267.47 \pm 120.58$ & $471.18 \pm 167.32$ & $\begin{array}{c}-7.075 \\
{[-260.846 \text { to }-146.570]}\end{array}$ & $<0.001^{*}$ \\
\hline APACHE-II Score & $16.95 \pm 7.25$ & $22.10 \pm 7.71$ & $\begin{array}{c}-3.391 \\
{[-8.164 \text { to }-2.136]}\end{array}$ & $<0.001^{*}$ \\
\hline
\end{tabular}

Table 3. Comparison of the Important Biomarkers of Mortality Observed in Sepsis among Two Different Comparative Groups of Recovery and Death as Survival Outcomes

*Indicates a significant statistical difference between the groups with $\mathrm{P}<0.05$.

The above table describes the mean values and standard deviations of C-reactive protein, Lactate dehydrogenase and APACHE-II scores.

The mean values of CRP in sepsis were $25.14 \pm 16.84$ $\mathrm{mg} / \mathrm{L}$. It ranged between $3-80 \mathrm{mg} / \mathrm{L}$. The mean values of Creactive proteins (CRP) was significantly higher among those who died $(36.40 \pm 18.92 \mathrm{mg} / \mathrm{L})$ compared to patients who recovered $(17.63 \pm 9.81 \mathrm{mg} / \mathrm{L})$ from sepsis $(\mathrm{t}=-6.493, \mathrm{p}=$ $<0.001)$. The mean values of serum lactate dehydrogenase (LDH) was significantly higher among those who died (471.18 $\pm 167.32 \mathrm{U} / \mathrm{L})$ compared to patients who recovered $(267.47 \pm 120.58 \mathrm{U} / \mathrm{L})$ from sepsis $(\mathrm{t}=-7.075, \mathrm{p}=<0.001)$.

The mean values of APACHE-II score was significantly higher among who died $(22.10 \pm 7.71)$ compared to patients who recovered $(16.95 \pm 7.25)$ from sepsis $(t=-3.391, p=<$ 0.001).

\begin{tabular}{|c|c|c|c|c|}
\hline Particulars & & $\begin{array}{c}\text { C-Reactive } \\
\text { Protein } \\
(\text { Mean } \pm \text { SD) }\end{array}$ & $\begin{array}{c}\text { t-value } \\
(95 \% \text { C.I })\end{array}$ & $\begin{array}{c}P \text { - } \\
\text { value }\end{array}$ \\
\hline \multirow{2}{*}{$\begin{array}{l}\text { 1. Age in } \\
\text { Years }\end{array}$} & $\leq 50$ & $23.46 \pm 15.09$ & \multirow{2}{*}{$\begin{array}{c}-1.079 \\
{[-10.349 \text { to- }} \\
3.057]\end{array}$} & \multirow[b]{2}{*}{$0.017^{*}$} \\
\hline & $>50$ & $27.11 \pm 18.67$ & & \\
\hline \multirow{2}{*}{ 2. Gender } & Male & $26.04 \pm 15.68$ & \multirow{2}{*}{$\begin{array}{c}0.586 \\
{[-4.751 \text { to } 8.735]}\end{array}$} & \multirow{2}{*}{0.559} \\
\hline & Female & $24.04 \pm 18.29$ & & \\
\hline \multirow{2}{*}{$\begin{array}{c}\text { 3. Organ } \\
\text { Involvement }\end{array}$} & $\geq 3$ & $27.06 \pm 18.37$ & \multirow{2}{*}{$\begin{array}{c}-1.715 \\
{[-13.346 \text { to- }} \\
0.972]\end{array}$} & \multirow[b]{2}{*}{0.09} \\
\hline & $<3$ & $20.87 \pm 12.01$ & & \\
\hline \multirow{2}{*}{$\begin{array}{l}\text { 4. Septic } \\
\text { Shock }\end{array}$} & Present & $23.13 \pm 16.04$ & \multirow{2}{*}{$\begin{array}{c}0.351 \\
{[-10.189 \text { to }} \\
14.569]\end{array}$} & \multirow[b]{2}{*}{0.73} \\
\hline & Absent & $25.32 \pm 16.99$ & & \\
\hline
\end{tabular}

Table 4. Comparison of C-Reactive Protein based on Organ Involvement in Sepsis
*Indicates a significant statistical difference between the groups with $\mathrm{P}<0.05$.

The mean values of C-reactive proteins (CRP) in sepsis was significantly higher among those who are aged $>50$ years $(27.11 \pm 18.67 \mathrm{mg} / \mathrm{L})$ compared to those who are aged $\leq 50$ years $(23.46 \pm 15.09 \mathrm{mg} / \mathrm{L})$; however, it was not statistically significant $(\mathrm{t}=-1.079, \mathrm{P}<0.05)$.

The mean values of C-reactive proteins (CRP) was higher among males $(26.04 \pm 15.68 \mathrm{mg} / \mathrm{L})$ compared to females $(24.04 \pm 18.29 \mathrm{mg} / \mathrm{L})$ in sepsis; however, it was not statistically significant $(\mathrm{t}=0.586, \mathrm{P}>0.05)$.

The mean values of C-reactive proteins (CRP) was higher among those with $\geq 3$ organs involvement $(27.06 \pm 18.37$ $\mathrm{mg} / \mathrm{L}$ ) compared to patients with $<3$ organs involvement $(20.87 \pm 12.01 \mathrm{mg} / \mathrm{L})$ in sepsis; however, it was not statistically significant $(\mathrm{t}=-1.715, \mathrm{P}>0.05)$.

The mean values of $\mathrm{C}$-reactive proteins (CRP) did not significantly differ among those with septic shock (23.13 \pm $16.04 \mathrm{mg} / \mathrm{L})$ compared to patients without (25.32 \pm 16.99 $\mathrm{mg} / \mathrm{L})$ septic shock $(\mathrm{t}=0.351, \mathrm{P}>0.05)$.

\begin{tabular}{|c|c|c|c|c|}
\hline \multirow[b]{2}{*}{ Variables } & & \multicolumn{2}{|c|}{ Outcome of Sepsis } & \multirow[b]{2}{*}{$\begin{array}{l}\chi^{2} \text { Value } \\
(P \text {-Value })\end{array}$} \\
\hline & & $\begin{array}{l}\text { Survived } \\
\text { (Row \%) }\end{array}$ & $\begin{array}{c}\text { Died } \\
(\text { Row \%) }\end{array}$ & \\
\hline \multirow{2}{*}{ CRP } & Normal & $00(0.0)$ & $00(0.0)$ & \\
\hline & Abnormal & $60(60.0)$ & $40(40.0)$ & \\
\hline \multirow{2}{*}{ LDH } & Normal & $58(78.4)$ & $16(21.6)$ & \multirow{2}{*}{$\begin{array}{c}40.05 \\
(<0.001) *\end{array}$} \\
\hline & Abnormal & $02(7.7)$ & $24(92.3)$ & \\
\hline \multirow{2}{*}{ GCS } & Normal & $45(70.3)$ & $19(29.7)$ & \multirow{2}{*}{$\begin{array}{c}7.87 \\
(0.005) *\end{array}$} \\
\hline & Abnormal & $15(41.7)$ & $21(58.3)$ & \\
\hline
\end{tabular}

Table 5. Association of Important Biomarkers of Mortality with the Outcome of Sepsis 
*Indicates a significant statistical difference between the groups with $\mathrm{P}<0.05$.

The CRP values were raised in both the outcomes of survivability in Sepsis and the values ranged between 0.5 $9.0 \mathrm{mg} / \mathrm{L}$. Among the patients who had raised LDH of $>450$ $\mathrm{U} / \mathrm{L}$, majority (92.3\%) did not survive from sepsis and the association was statistically significant $(\mathrm{P}<0.05)$. Among the patients with the GCS of $<15$, most (58.3\%) of them died and the association was statistically significant $(\mathrm{P}<0.05)$.

\begin{tabular}{|c|c|c|c|c|}
\hline \multirow{2}{*}{ Variables } & & \multicolumn{2}{|c|}{ Outcome of Sepsis } & \multirow{2}{*}{$\begin{array}{c}\chi^{2} \text { Value } \\
\text { (P-Value) }\end{array}$} \\
\cline { 2 - 4 } & $\begin{array}{c}\text { Survived } \\
\text { (Column } \\
\text { \%) }\end{array}$ & $\begin{array}{c}\text { Died } \\
\text { (Column \%) }\end{array}$ & \\
\hline \multirow{2}{*}{ CRP } & $\leq 18$ & $43(71.7)$ & $11(27.5)$ & 18.85 \\
& $>18$ & $17(28.3)$ & $29(72.5)$ & $(<0.001)^{*}$ \\
\hline \multirow{2}{*}{ LDH } & $\leq 340$ & $40(66.7)$ & $11(27.5)$ & 14.73 \\
\cline { 2 - 4 } & $>340$ & $20(33.3)$ & $29(72.5)$ & $(<0.001)^{*}$ \\
\hline \multirow{2}{*}{ APACHE-II } & $\leq 18$ & $41(68.3)$ & $16(40.0)$ & 7.87 \\
\cline { 2 - 4 } & $>18$ & $19(31.7)$ & $24(60.0)$ & $(0.005) *$ \\
\hline \multicolumn{3}{|l|}{$\begin{array}{l}\text { Table 6. Association of Important Biomarkers of Mortality with } \\
\text { Cut-Off of Respective Median Values with the Outcome of Sepsis }\end{array}$} \\
\hline
\end{tabular}

*Indicates a significant statistical difference between the groups with $\mathrm{P}<0.05$.

The proportion of patients who died were significantly more among those (72.5\%) with CRP and LDH values of more than $18 \mathrm{mg} / \mathrm{L}$ and $340 \mathrm{U} / \mathrm{L}$ respectively compared to those $(27.5 \%)$ with CRP and $\mathrm{LDH}$ values $\leq 18 \mathrm{mg} / \mathrm{L}$ and $\leq 340 \mathrm{U} / \mathrm{L}$ respectively $(\mathrm{P}<0.05)$. The proportion of patients who died were significantly more among those $(60.0 \%)$ with APACHEII values $>18$ compared to those $(40.0 \%)$ with values $\leq 18$ $(\mathrm{P}<0.05)$.

\begin{tabular}{|c|c|c|c|}
\hline Variables & CRP & LDH & APACHE-II \\
\hline CRP & 1 & & \\
\hline LDH & $0.576^{*}(<0.001)$ & 1 & \\
\hline APACHE-II & $0.008(0.937)$ & $0.012(0.090)$ & 1 \\
\hline
\end{tabular}

Figures in parenthesis indicate $P$-value.

*Pearson Correlation value is significant $(<0.05)$

With the above table, it can be observed that among patients with Sepsis, C-reactive protein, Lactate dehydrogenase and APACHE-II scores are positively correlated to each other. However, only Lactate dehydrogenase had significant positive correlation with CRP $(r=0.576, P<0.05)$, i.e. with increase in LDH values there was significant increase in CRP values.

\begin{tabular}{|c|c|c|c|}
\hline $\begin{array}{c}\text { Parameters } \\
\text { Predicting } \\
\text { Mortality in } \\
\text { Sepsis }\end{array}$ & P-value & $\begin{array}{c}\text { Odds } \\
\text { Ratio }\end{array}$ & $\mathbf{9 5 \%}$ CI \\
\hline LDH & & 0.989 & $0.984-0.995$ \\
APACHE-II Score & $<0.001^{*}$ & 0.808 & $0.720-0.907$ \\
C-Reactive Protein & 0.936 & $0.894-0.984$ \\
\hline \multicolumn{1}{|c|}{ Table 8. Comparison of Important Biomarkers of Mortality } \\
among Sepsis Patients using Logistic Regression \\
\hline
\end{tabular}

*Indicates a significant statistical difference between the groups with $P<0.05$.
After entering the variables (significant on univariate analysis) in the logistic regression model with forward method we found that LDH, APACHE-II and CRP were the significant predictors $(P<0.05)$, which fits the model according to Hosmer-Lemeshow Goodness of fit $(P>0.05)$. The overall row percentage in the model with all $\mathrm{LDH}$, APACHE-II and CRP showed the best accuracy (87.0\%) in predicting the outcome of sepsis. LDH is one of the independent strong predictors of Sepsis by itself with adjusted $\mathrm{OR}=0.989,95 \%$, C.I $0.984-0.995, P<0.05$ which shows that with unit rise in LDH the odds of survival reduce by $98.0 \%$ among patients with sepsis. CRP with adjusted OR= $0.936,95 \%$, C.I. $0.894-0.984$ and $P<0.05$ shows that with unit rise in CRP the odds of survival reduces by $93.0 \%$ and in APACHE-II with adjusted OR $=0.808,95 \%$, C.I. $0.720-0.907$ and $P<0.05$ shows that with unit rise in APACHE-II the odds of survival reduces by $80.0 \%$ among patients with sepsis.

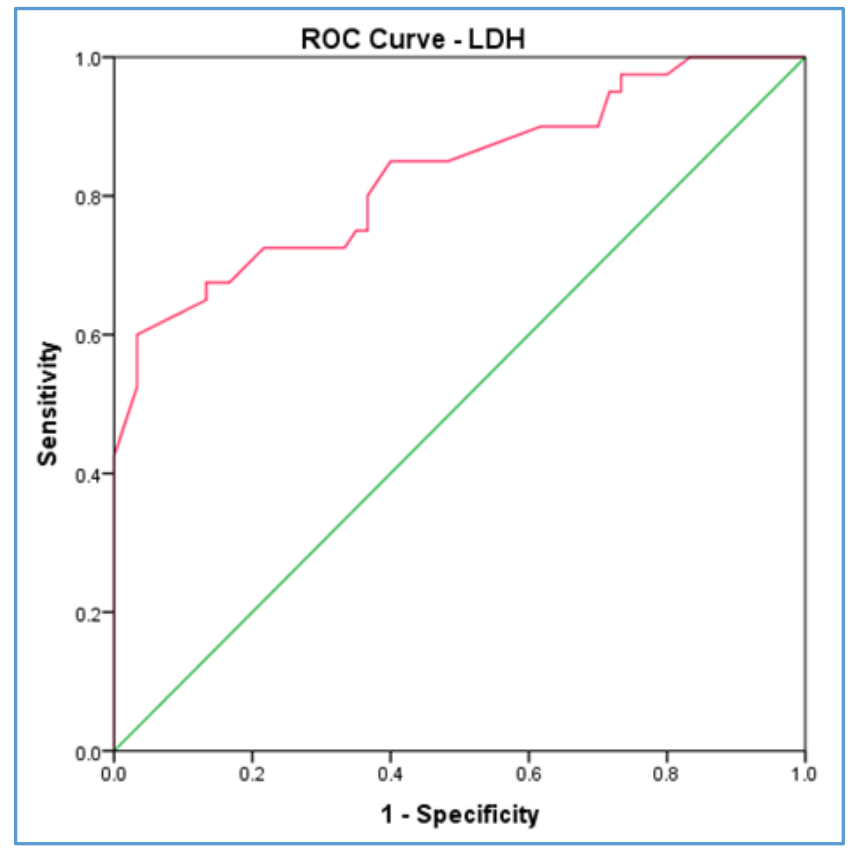

Graph 1. ROC Curve for CRP 4 (A), LDH 4 (B), APACHE-II Scores 4 (C) in Predicting the Mortality in Sepsis (Graph 1A)

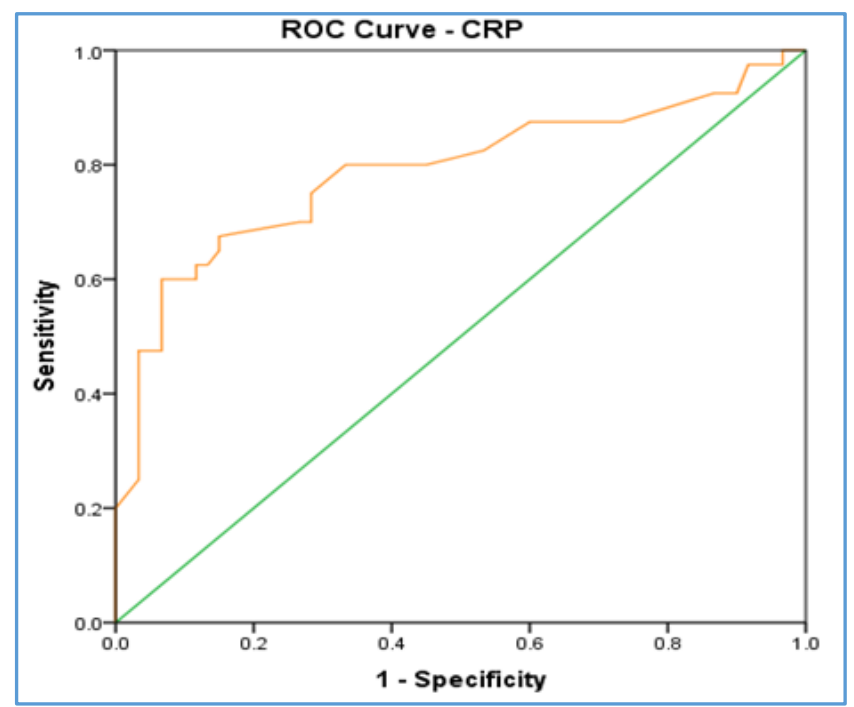

Graph 1B 


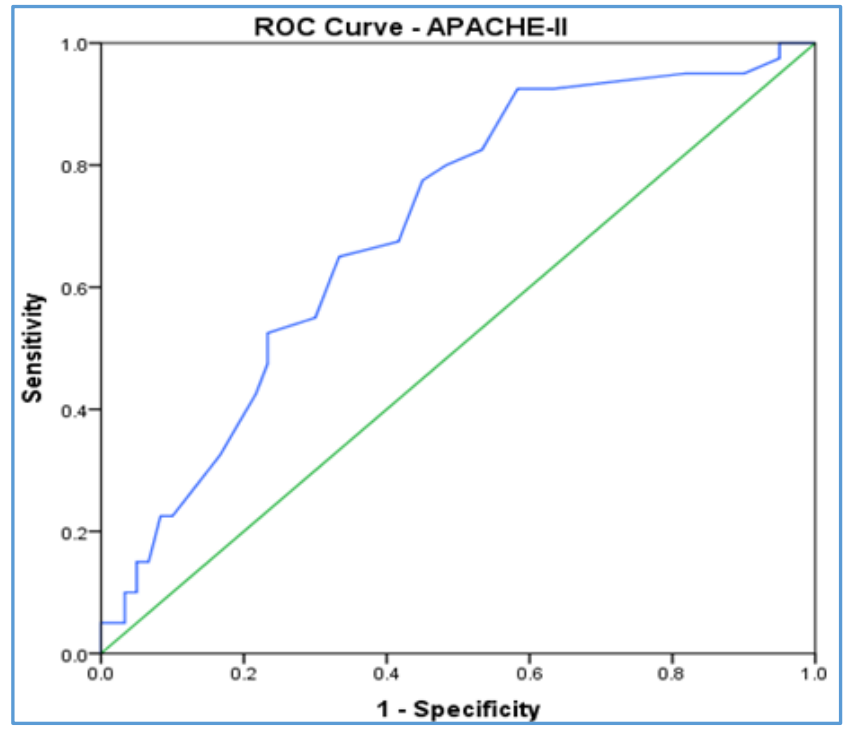

Graph 1C

The ROC curve obtained by plotting at different cut-offs of values of CRP, LDH and APACHE-II Scores are shown in Graph $1 \mathrm{~A}, 1 \mathrm{~B}$ and $1 \mathrm{C}$. The areas under the curve in Graphs $1 \mathrm{~A}, 1 \mathrm{~B}$ and $1 \mathrm{C}$ for $\mathrm{LDH}$ is 0.831 with SE of 0.044 at $95 \% \mathrm{CI}$ ranging from 0.746 to $0.916(\mathrm{P}<0.05)$; for CRP is 0.788 with SE of 0.051 at $95 \% \mathrm{CI}$ ranging from 0.688 to 0.888 ( $\mathrm{P}<0.05)$; and for APACHE-II Scores is 0.699 with SE of 0.053 at $95 \%$ CI ranging from 0.595 to $0.802(P<0.05)$ respectively. The larger the AUC, the better is the predictive capacity in identifying the cut-off scores to predict the mortality in patients with Sepsis.

The best cut-off that maximises both sensitivity and specificity for LDH is $458.5 \mathrm{U} / \mathrm{L}$ with sensitivity of $60.0 \%$ and specificity of $93.0 \%$; for CRP, the cut-off is $33 \mathrm{mg} / \mathrm{L}$ with sensitivity of $60 \%$ and specificity of $93.3 \%$ and for APACHE-II scores the cut-off score is 13.5 with sensitivity being $92.5 \%$ and specificity being $41.7 \%$.

Hence, on comparing the area under the curves, $\mathrm{LDH}$ is a good indicator of mortality among patients with sepsis compared to CRP and APACHE-II scores. The next best indicator is CRP followed by APACHE-II scores.

\section{DISCUSSION}

Sepsis is among the most common causes of death in hospitalised patients. The clinical profile of 100 patients with sepsis was studied. Majority were (55.0\%) males and rest $(45.0 \%)$ were females. The age of patients varied from $18 \mathrm{yrs}$. to $90 \mathrm{yrs}$. The mean age of the individuals was $49.78+/$ 17.13 yrs. The mean age of men and women were $52.58+/-$ 15.14 yrs. and $49.78+/-17.13$ yrs. respectively. Most of the patients in the present study were in $4^{\text {th }}$ to $5^{\text {th }}$ decade. Similar studies in India have shown male preponderance with most patients in the $4^{\text {th }}$ to $5^{\text {th }}$ decade. ${ }^{10}$

\section{Clinical Predictors of Mortality}

In our study, 40 (40.0\%) patients died and 60 (60.0\%) patients survived. Totally, $8(8.0 \%)$ had septic shock. Studies have shown that age is not an important predictor of mortality in ICU patients with severe sepsis. ${ }^{11}$ The mean age among non-survivors was a little high compared to survivors (51.30 v/s 48.77), which was not statistically significant ( $\mathrm{p}=$ 0.47). In our study, majority i.e. $55(55.0 \%)$ being males.
Among the patients who died of sepsis and recovered from sepsis, most of them were males.

The proportion of patients $(77.5 \%)$ who died with $\geq 3$ organs involvement were significantly more compared to those $(22.5 \%)$ with $<3$ organs involvement $(\mathrm{P}<0.05)$. It has been found that anaemia is highly prevalent in the critically ill and it may be associated with poor patient outcomes.12 Among the patients with septic shock, majority (75.0\%) did not recover and the association was statistically significant $(P<0.05)$. Several clinical trials have demonstrated a mortality ranging from $40 \%$ to $75 \%$ in patients with MODS arising from sepsis. ${ }^{13}$

The mean values of C-reactive proteins (CRP) was significantly higher among those who died (36.40 \pm 18.92 $\mathrm{mg} / \mathrm{L})$ compared to patients who recovered (17.63 \pm 9.81 $\mathrm{mg} / \mathrm{L}$ ) from sepsis ( $\mathrm{t}=-6.493, \mathrm{p}=<0.001)$. The mean values of C-reactive proteins (CRP) in sepsis was significantly higher among those aged $>50$ years $(27.11 \pm 18.67 \mathrm{mg} / \mathrm{L})$ compared to those aged $\leq 50$ years $(23.46 \pm 15.09 \mathrm{mg} / \mathrm{L})$; however, it was not statistically significant $(\mathrm{t}=-1.079, \mathrm{P}<0.05)$. The mean values of C-reactive proteins (CRP) was higher among males $(26.04 \pm 15.68 \mathrm{mg} / \mathrm{L})$ compared to females $(24.04 \pm$ $18.29 \mathrm{mg} / \mathrm{L}$ ) in sepsis; however, it was not statistically significant ( $\mathrm{t}=0.586, P>0.05$ ). The mean CRP values of CRP was higher among those with $>3$ organs involvement compared to patients with $<3$ organs involvement in sepsis. The mean values of C-reactive proteins (CRP) did not significantly differ among those with septic shock (23.13 \pm $16.04 \mathrm{mg} / \mathrm{L})$ compared to patients without $(25.32 \pm 16.99$ $\mathrm{mg} / \mathrm{L})$ septic shock $(\mathrm{t}=0.351, \mathrm{P}>0.05)$. However, it was not statistically significant.

The mean values of APACHE-II score was significantly higher among who died $(22.10 \pm 7.71)$ compared to patients who recovered $(16.95 \pm 7.25)$ from sepsis $(t=-3.391, p=<$ 0.001 ). The findings are similar to a study conducted by Deepak CL and Bhat S has found mean APACHE-II score in patients who died of 24.2 compared to the patients who recovered from the illness of 18.5 ( $p$ value 0.002 ). ${ }^{14}$

The mean values of serum lactate dehydrogenase (LDH) was significantly higher among those who died (471.18 \pm 167.32 U/L) compared to patients who recovered (267.47 \pm $120.58 \mathrm{U} / \mathrm{L})$ from sepsis $(\mathrm{t}=-7.075, \mathrm{p}=<0.001)$. In a study conducted by Zein JG et al, LDH was found as a marker of cell injury which reflects the degree of tissue damage and the deaths were significantly associated with a higher LDH level $(656 \pm 79 \mathrm{U} / \mathrm{L})$ compared to survivors $(369 \pm 72 \mathrm{U} / \mathrm{L})$ and it was commonly seen in patients with severe sepsis. ${ }^{15}$

We have found that LDH, APACHE-II and CRP were the significant predictors of mortality in sepsis. The same evidences are also elucidated in some of the studies conducted elsewhere.15,16,17

\section{Limitations}

The values of CRP, LDH and APACHE-II have been considered only on the day of admission and the follow-up data and change in the levels would be more sensitive in predicting mortality in sepsis.

\section{CONCLUSION}

The mean values of CRP in sepsis were $25.14 \pm 16.84 \mathrm{mg} / \mathrm{L}$. It ranged between $3-80 \mathrm{mg} / \mathrm{L}$. The mean values of C-reactive protein (CRP) was significantly higher among those who died 
(36.40 $\pm 18.92 \mathrm{mg} / \mathrm{L})$ compared to patients who recovered $(17.63 \pm 9.81 \mathrm{mg} / \mathrm{L})$ from sepsis $(\mathrm{t}=-6.493, \mathrm{p}=<0.001)$.

The mean values of C-reactive proteins (CRP) in sepsis was significantly higher among those who aged $>50$ years $(27.11 \pm 18.67 \mathrm{mg} / \mathrm{L})$ compared to those who aged $\leq 50$ years $(23.46 \pm 15.09 \mathrm{mg} / \mathrm{L})$; however, it was not statistically significant $(\mathrm{t}=-1.079, P<0.05)$.

The mean values of C-reactive proteins (CRP) was higher among males $(26.04 \pm 15.68 \mathrm{mg} / \mathrm{L})$ compared to females $(24.04 \pm 18.29 \mathrm{mg} / \mathrm{L})$ in sepsis; however, it was not statistically significant $(\mathrm{t}=0.586, P>0.05)$.

The mean values of C-reactive proteins (CRP) was higher among those with $\geq 3$ organs involvement $(27.06 \pm 18.37$ $\mathrm{mg} / \mathrm{L}$ ) compared to patients with $<3$ organs involvement $(20.87 \pm 12.01 \mathrm{mg} / \mathrm{L})$ in sepsis; however, it was not statistically significant $(\mathrm{t}=-1.715, P=0.09)$.

The mean values of C-reactive proteins (CRP) was higher among those with septic shock (29.62 $\pm 23.12 \mathrm{mg} / \mathrm{L})$ compared to patients without $(23.95 \pm 14.70 \mathrm{mg} / \mathrm{L})$ septic shock; however, it was not statistically significant $(\mathrm{t}=-1.377$, $P=0.17$ ).

The proportion of patients who died were significantly more among those with CRP more than $18 \mathrm{mg} / \mathrm{L}$ compared to those with $\leq 18 \mathrm{mg} / \mathrm{L}$.

APACHE-II and CRP were the significant independent predictors. Among CRP and APACHE-II, the best indicator of mortality in sepsis was CRP followed by APACHE-II scores. LDH was also one of the significant independent predictors. The combined model with LDH, APACHE-II and CRP showed the best accuracy of $87.0 \%$ in predicting the outcome of sepsis. Among the patients with sepsis the unit rise in LDH reduces the odds of survival by $98.0 \%$, the unit rise in CRP the odds of survival reduce by $93.0 \%$ and with unit rise in APACHE-II score the odds of survival reduces by $80.0 \%$.

$\mathrm{LDH}$ is a good indicator of mortality among patients with sepsis compared to CRP and APACHE-II.

\section{REFERENCES}

[1] Maler RV. Approach to patient with shoch. Harrison's Principles of internal medicine. 19th edn. 2015:1744-5.

[2] Richard S, Irwin MD, James M. Irwin and Rippes's Intensive care medicine, $6^{\text {th }}$ edn. Philadelphia: Wolters Kluwer/Lippincott Williams \& Wilkins 2008.

[3] Kollef MH, Sherman G, Ward S, et al. Inadequate antimicrobial treatment of infections: a risk factor for hospital mortality among critically ill patients. Chest 1999;115(2):462-74.

[4] Bochud PY, Glauser MP, Calandra T. Antibiotics in sepsis. Intensive Care Med 2001;27(Suppl 1):S33-48.
[5] Leibovici L, Shraga I, Drucker M, et al. The benefit of appropriate empirical antibiotic treatment in patients with bloodstream infection. J Intern Med 1998;244(5):379-86.

[6] Balk RA. Optimum treatment of severe sepsis and septic shock: evidence in support of the recommendations. Dis Mon 2004;50(4):168-213.

[7] Heart Protection Study Collaborative Group, Emberson J, Bennett D, et al. C-reactive protein concentration and the vascular benefits of statin therapy: an analysis of 20,536 patients in the Heart Protection Study. Lancet 2011;377(9764):469-76.

[8] Swardfager W, Herrmann N, Cornish S, et al. Exercise intervention and inflammatory markers in coronary artery disease: a meta-analysis. American Heart Journal 2012;163(4):666-76.el-3.

[9] Dellinger RP, Levy MM, Carlet JM, et al. Surviving sepsis campaign: International guidelines for management of severe sepsis and septic shock: 2008. Crit Care Med 2008;36(1):296-327.

[10] Todi S, Chatterjee S, Sahu S, et al. Epidemiology of severe sepsis in India: an update. Crit Care 2010;14(Suppl 1):P382.

[11] Chin-Ming Chen, Kuo-Chen Cheng, Khee-Siang Chan, et al. Age may not influence the outcome of patients with severe sepsis in ICU. International Journal of Gerontology 2014;8(1):22-6.

[12] Hayden SJ, Albert TJ, Watkins TR, et al. Anemia in critical illness: insights into etiology, consequences and management. American Journal of Respiratory and Critical Care Medicine 2012;185(10):1049-57.

[13] Al-Khafaji, Ali H. Multiple organ dysfunction syndrome in sepsis. $\quad$ Medscape 2017 http://emedicine.medscape.com/article/169640overview\#a6.

[14] Deepak CL, Smitha B. Prediction of outcome in patients with sepsis using $C$ - reactive protein \& APACHE II scoring system. IOSR-JDMS 2014;13(3):Ver. V. 17-20.

[15] http://journal.publications.chestnet.org/article.aspx?a rticleid $=1092000$

[16] Ho KM, Lee KY, Dobb GJ, et al. C-reactive protein concentration as a predictor of in-hospital mortality after ICU discharge: a prospective cohort study. Intensive Care Med 2008;34(3):481-7.

[17] Arabi Y, Al-Shirawi N, Memish Z, et al. Assessment of six mortality prediction models in patients admitted with severe sepsis and septic shock to the intensive care unit: a prospective cohort study. Crit Care 2003;7(5):R116-R22. 